\section{Isolation and Screening of Mycorrhizal Fungi from Citrus Nurseries and Orchards and Inoculation Studies}

\author{
Amelia Camprubí and Cinta Calvet \\ Institut de Recerca i Tecnologia Agroalimentàries, Departament de Patologia \\ Vegetal, Centre de Cabrils, Crta. de Cabrils s/n, 08348 Cabrils, Barcelona, \\ Spain
}

Additional index words. Glomus intraradices, Glomus mosseae, infectivity, rootstocks

\begin{abstract}
The selection of the most effective arbuscular mycorrhizal (AM) fungi for growth enhancement of citrus cultivars used as rootstocks was the first step toward development of an AM inoculation system in citrus nurseries in Spain. AM fungi were isolated from citrus nurseries and orchards in the major citrus-growing areas of eastern Spain. The most common AM fungi found in citrus soils belonged to Glomus species, and G. mosseae (Nicol. \& Gerd.) Gerdemann \& Trappe and $G$. intraradices Schenck \& Smith were the AM fungi most frequently associated with citrus roots. The most effective fungus for growth enhancement of citrus rootstocks was $G$. intraradices. Significant differences in mycorrhizal dependency among rootstocks were confirmed. Sour orange (Citrus aurantium $L$.) and Cleopatra mandarin $(C$. reshni $\mathrm{L}$.) were more dependent than Troyer citrange $[C$. sinensis (L.) Obs. x Poncirus trifoliata (L.) Raf.] and Swingle citrumelo (C. paradisi Macf. $\mathbf{x} P$. trifoliata). Moreover, several inoculation systems for plant production were evaluated for their effectiveness in promoting root colonization of the rootstock cultivars.
\end{abstract}

The occurrence of arbuscular mycorrhizae (AM) in citrus was reported for the first time in 1933 (Reed and Fremont, 1935). Due to the economic importance of citriculture and to the relatively high mycorrhizal dependency of citrus species, nursery inoculation with AM fungi has received great attention in recent decades (Graham, 1986). There is renewed interest in them, now that stunting of plantlets in Spanish citrus nurseries has been associated with their absence.

Before the application of mycorrhizal inoculation is considered, the response of citrus in the field should be evaluated (Graham, 1986). Initially, it is important to identify the native mycorrhizal fungi associated with the crop in the field and to isolate them to screen for their effectiveness in promoting plant growth under greenhouse and, eventually, field conditions.

Although AM fungi are not host-specific, previous studies have shown that mycorrhizal fungi vary widely in their effectiveness (Graham et al., 1982). Other studies indicate that citrus rootstocks vary widely in their mycorrhizal dependency (Graham and Syvertsen,

Received for publication 12 Oct. 1995. Accepted for publication 2 Feb. 1996. We thank Christopher Walker from The Forestry Commission (United Kingdom) for his advice and encouragement in the classification of arbuscular mycorrhizal fungi and the Servicio de Protección de los Vegetales de Valencia (Spain) and the Estació Experimental de l'Ebre (IRTA-Amposta, Tarragona, Spain) for providing orchards and citrus nurseries. This work has been funded by Viveros Gurbí (Alcanar, Tarragona, Spain). The cost of publishing this paper was defrayed in part by the payment of page charges. Under postal regulations, this paper therefore must be hereby marked advertisement solely to indicate this fact.
1985; Nemec, 1978) and that selection of AM fungi for a particular citrus rootstock under specific edaphic conditions may be necessary (Graham et al., 1982).

The first objective of this study was to isolate and identify AM fungi from citrus growing regions of eastern Spain. The second objective was to confirm the previously recognized differences in relative dependency for four citrus rootstocks (Graham, 1986) used in citrus nurseries in Spain: Troyer citrange and Cleopatra mandarin (both extensively used as citrus rootstocks), sour orange (the most used in the past in Spanish orchards), and Swingle citrumelo. The third objective was to evaluate preliminarily several inoculation systems for greenhouse production of citrus rootstock seedlings.

\section{Materials and Methods}

Isolation of AM fungi. Soil and root samples from 30 citrus orchards and nurseries in the major citrus-growing regions of eastern Spain were collected. Nine rootstocks were sampled: sour orange, Carrizo citrange and Troyer citrange, Swingle citrumelo, Cleopatra mandarin, Rangpur lime (Citrus limonia Obs.), $C$. volkameriana Ten. \& Pasq., C. taiwanica Tan. \& Shim., and C. macrophylla Webster (Ortiz, 1986). The samples collected from $C$. taiwanica, C. macrophylla, C. volkameriana, and Cleopatra mandarin were taken from seedbeds and nurseries (1- to 2-year-old trees). Carrizo citrange, Troyer citrange, Rangpur lime, and Swingle citrumelo samples were collected in orchards 5 to 10 years old. The samples from sour orange, the traditional rootstock used in Spain before the detection of citrus tristeza virus, were taken from seednurseries and orchards from the major citrus- beds, nurseries, and orchards with 5- to 10-, 25-, and 80-year-old trees.

Four soil and root cores (20 cm deep and $1000 \mathrm{~cm}^{3}$ in volume) were collected under each tree. The four samples of each location and tree were combined into a single sample. Citrus roots were extracted, washed free of soil and debris, cleared and stained (Koske and Gemma, 1989; Phillips and Hayman, 1970), and examined under a microscope for the presence of mycorrhizal colonization.

To estimate the number of infective AM fungal propagules per cubic centimeter of soil, the most probable number (MPN) was determined using 10-fold series of soil dilutions with autoclaved soil as a diluent (Porter, 1979; Powell, 1980).

The AM fungus spores present in the soil samples were recovered by wet sieving and decanting (Gerdemann and Nicolson, 1963). The classification of AM fungi is based on the morphology of spores; thus, fungi not present as spores in soil samples cannot be recognized. Nonsporulating fungi were detected by two complementary methods (Camprubí et al., 1987):

1) Use of a trap plant. The soil collected from the various sites was placed in pots, and leek (Allium porrum L.), clover (Trifolium repens $\mathrm{L}$.), lavender (Lavandula vera $\mathrm{L}$.), and Citrus spp. seedlings were transplanted into the soil to allow AM fungi to colonize roots and complete their life cycle by forming chlamydospores in the soil.

2) Use of Citrus roots colonized with native AM fungi. Seedlings of clover and onion (Allium cepa L.) were inoculated with colonized citrus roots that were placed under the clover and onion roots in individual containers filled with autoclaved sandy soil.

Every 2 months during 1 year, rhizosphere soil was sampled to assess the presence of AM spores and to extract them by wet sieving and decanting (Gerdemann and Nicolson, 1963). The identification of spores was done according to Schenck and Perez (1988).

To establish pure AM fungal pot cultures, spores separated directly from field soils and spores recovered during the isolation process were used as inoculum.

Relative dependency of citrus rootstocks. To assess the effects of AM fungi on the growth of Troyer citrange, Cleopatra mandarin, Swingle citrumelo, and sour orange, inocula of three Glomus species isolated from the citrus nurseries were evaluated: $G$. intraradices; $G$. mosseae; and a mixed inoculum including $G$. intraradices, $G$. mosseae, $G$. aggregatum Schenck \& Smith, and associated microbiota. The inoculum consisted of rhizosphere soil and colonized roots of barley $(H$. vulgare) harvested from pot cultures obtained after 4 months growth in a sandy soil. At this time, the major source of inoculum was infected roots. For this reason the colonization percentage of root samples was assessed using the gridline intersect method (Giovannetti and Mosse, 1980) after clearing and staining the roots (Koske and Gemma, 1989). The colonization percentage in barley roots was $64 \% \pm$ $10 \%$ for $G$. mosseae, $79 \% \pm 9 \%$ for $G$. 
intraradices, and $54 \% \pm 15 \%$ for mixed inoculum (means of 20 plants \pm SD). The colonized roots were cut and mixed with the planting soil.

Ten plants of each rootstock were inoculated in individual pots with the selected AM fungi, and a noninoculated treatment was added as a control. Inoculum (10 g) was placed below the citrus seedling roots in the autoclaved sandy soil at transplanting.

After 5 months of growth, plants were harvested and relative mycorrhizal dependency (RMD) of all citrus rootstocks was calculated according to Plenchette et al. (1983) using shoot dry weight of plants. RMD is between 0 (no AM dependence) to 100 (total AM dependence).

To select the most effective AM fungus in promoting rootstock growth and development, we measured shoot and root dry weights, shoot length, root : shoot dry weight ratio, stem diameter, and foliar area of plants inoculated with localized inoculum.

Greenhouse inoculation systems. The same inocula, including soil and colonized root fragments of barley, were used as the source of inoculum for G. intraradices, G. mosseae, and the mixed inoculum treatments. The inoculation systems studied were 1) localized inoculation (inoculum placed under the growing roots of citrus plantlets); 2) uniform distribution of the inoculum in the substrate (inoculum mixed with the planting medium); 3 ) one layer of inoculum between two layers of planting substrate; 4) inoculum distributed homogeneously in the container seedbed; and 5) inoculation with mycorrhizal plants of lavender, 6) thyme (Thymus vulgaris L.), and 7) rosemary (Rosmarinus officinalis L.) introduced in the planting medium 2 months before sowing citrus seeds. The effects of inoculation systems 1,2, and 3 on infection success were studied for $G$. mosseae, $G$. intraradices, and mixed inoculum. Inoculation of the seedbed containers (systems 4, 5, 6, and 7) was evaluated for $G$. intraradices only. The planting medium was a mixture of 1 sphagnum peat : 3 sand : 2 perlite (by volume) to fill $20-\mathrm{L}$ containers.

After 5 months, 10 plants of each inoculation treatment were harvested. Roots were cleared and stained (Koske and Gemma, 1989) and the internal colonization was assessed under a compound microscope in 100 root segments $(1 \mathrm{~cm}$ each) mounted on slides (Giovannetti and Mosse, 1980), since the gridline intersect method (Giovannetti and Mosse, 1980), most often used to measure the root colonization percentage, was not suitable due to the presence of a heavily lignified hypodermal layer and to the small size of cortical cells in citrus roots (Graham et al., 1991).

Inoculum density. Inoculation success with roots of barley colonized by G. mosseae was poor. To determine if the source of inoculum was a factor, the infectivity of roots colonized by G. mosseae or spores was compared. Twelve plantlets of leek and 12 sour orange seedlings were inoculated with each kind of inoculum: 1) 10 spores of $G$. mosseae localized over the roots and 2) 15 fragments (5 $\mathrm{mm}$ each) of mycorrhizal $H$. vulgare roots with a root colonization percentage of $64 \%$. Plants were harvested 6 and 12 weeks after inoculation, and root colonization percentage was assessed (Giovannetti and Mosse, 1980; Graham et al., 1991) after clearing and staining with trypan blue in lactic acid (Koske and Gemma, 1989; Phillips and Hayman, 1970).

Similarly, the number of infective propagules in the rhizosphere soil of citrus rootstocks was compared with the number of infective propagules in the rhizosphere soil of leek using the MPN technique (Porter, 1979; Powell, 1980). The effects of inoculum densities on inoculation success were evaluated. The inoculum used was rhizosphere soil containing spores, mycelia, and colonized roots of leek. The MPN was determined using a 10fold series of inoculum dilutions with autoclaved sandy soil as the diluent. Five seedlings of leek, sour orange, Cleopatra mandarin, Troyer citrange, and Swingle citrumelo were transplanted in each inoculum dilution. Results were evaluated using table VIII of Fisher and Yates (1963).

\section{Results}

Isolation of AM fungi. Citrus roots in all the sites sampled were colonized by AM fungi, without exceptions. Host rootstock or host age had no effect on internal colonization. The MPN of AM propagules (no./100 $\mathrm{cm}^{3}$ of soil) was higher in the seedbeds (758) and in young orchards (27 to 173 ) than in the oldest orchards of sour orange (2 to 17).

The AM fungi isolated in the soil samples of citrus nurseries and orchards included nine species of Glomus, and one species each of Acaulospora, Gigaspora, Sclerocystis, and Scutellospora (Table 1). The most common mycorrhizal fungi associated with citrus in eastern Spain were $G$. mosseae and $G$. intraradices (Fig. 1). These fungi were found in all soils sampled.

Relative dependency of citrus rootstocks. All rootstocks inoculated with localized inoculum, except for Swingle citrumelo, had longer shoots and a higher shoot dry weight than noninoculated plants (Table 2). Increased shoot growth reduced the root dry weight : shoot dry weight ratio $(\mathrm{R}: \mathrm{S})$ in noninoculated

Table 1. Arbuscular mycorrhizal fungi isolated in the soil samples of citrus nurseries and orchards.

Glomus aggregatum Schenck \& Smith emend. Koske

G. clarum Nicolson \& Schenck

G. diaphanum Morton \& Walker

G. etunicatum Becker \& Gerdemann

G. fasciculatum (Thaxter) Gerdemann \& Trappe emend. Walker and Koske

G. intraradices Schenck \& Smith

G. microaggregatum Koske, Gemma \& Olexia

G. monosporum Gerdemann \& Trappe

G. mosseae (Nicol.\& Gerd.) Gerdemann \& Trappe

Acaulospora sp.

Gigaspora sp.

Sclerocystis sinuosa Gerdemann \& Bakshi

Scutellospora $\mathrm{sp}$.

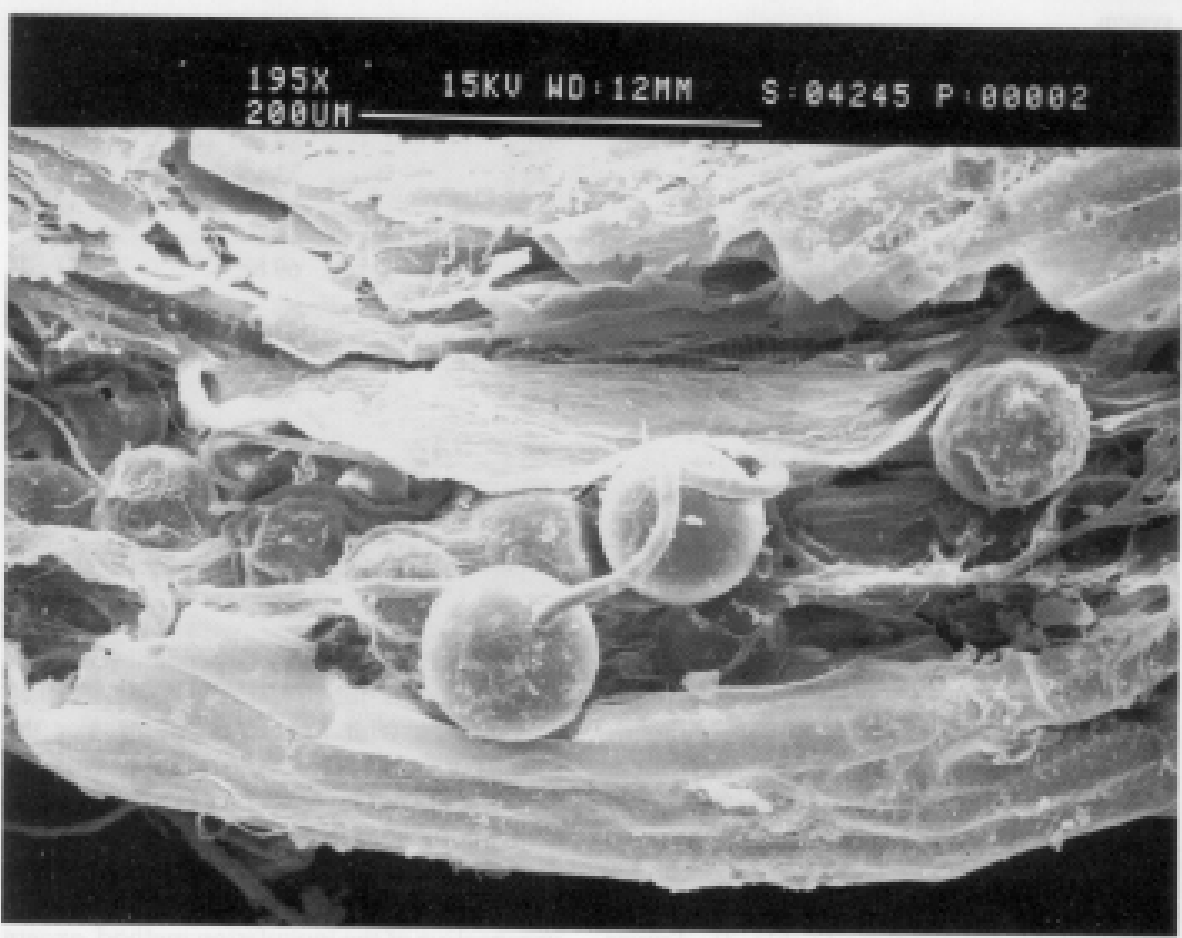

Fig. 1. Internal spores and mycelia of Glomus intraradices colonizing Allium porrum roots isolated from citrus nurseries (scanning electron microscope). 
Table 2. Plant growth characteristics and root : shoot dry weights ratio $(\mathrm{R}: \mathrm{S})$ of Swingle citrumelo, Troyer citrange, Cleopatra mandarin, and sour orange inoculated with Glomus intraradices, G. mosseae, a mixture of the two species plus G. aggregatum (mixed inoculum), and noninoculated control. ${ }^{2}$

\begin{tabular}{llccccc}
\hline \hline \multirow{2}{*}{ Rootstock } & Inoculum & $\begin{array}{c}\text { Shoot length } \\
(\mathrm{cm})\end{array}$ & $\begin{array}{c}\text { Stem diam } \\
(\mathrm{cm})\end{array}$ & $\begin{array}{c}\text { Foliar area } \\
\left(\mathrm{cm}^{2}\right)\end{array}$ & $\begin{array}{c}\text { Shoot dry wt } \\
(\mathrm{g})\end{array}$ & $\mathrm{R}: \mathrm{S}$ \\
\hline Swingle citrumelo & None & $5.9 \mathrm{~b}$ & $1.6 \mathrm{~b}$ & $4.6 \mathrm{~b}$ & $0.10 \mathrm{~b}$ & 1.00 \\
& G. mosseae & $8.1 \mathrm{a}$ & $1.9 \mathrm{a}$ & $6.4 \mathrm{~b}$ & $0.14 \mathrm{~b}$ & 0.94 \\
& G. intraradices & $8.0 \mathrm{a}$ & $1.8 \mathrm{ab}$ & $4.3 \mathrm{~b}$ & $0.13 \mathrm{~b}$ & 1.12 \\
Troyer citrange & Mixed & $8.9 \mathrm{a}$ & $1.9 \mathrm{a}$ & $15.2 \mathrm{a}$ & $0.22 \mathrm{a}$ & 0.78 \\
& None & $8.8 \mathrm{~b}$ & $2.0 \mathrm{a}$ & $8.9 \mathrm{~b}$ & $0.18 \mathrm{~b}$ & 0.93 \\
& G. mosseae & $10.7 \mathrm{ab}$ & $2.4 \mathrm{a}$ & $19.6 \mathrm{ab}$ & $0.28 \mathrm{ab}$ & 0.62 \\
& G. intraradices & $12.1 \mathrm{a}$ & $2.4 \mathrm{a}$ & $28.6 \mathrm{a}$ & $0.39 \mathrm{a}$ & 0.65 \\
Cleopatra mandarin & Mixed & $12.1 \mathrm{a}$ & $2.2 \mathrm{a}$ & $25.7 \mathrm{a}$ & $0.35 \mathrm{a}$ & 0.67 \\
& None & $6.4 \mathrm{c}$ & $1.6 \mathrm{c}$ & $10.1 \mathrm{~b}$ & $0.13 \mathrm{c}$ & 1.16 \\
& G. mosseae & $8.5 \mathrm{bc}$ & $1.9 \mathrm{bc}$ & $21.1 \mathrm{~b}$ & $0.24 \mathrm{bc}$ & 0.85 \\
& G. intraradices & $12.9 \mathrm{a}$ & $2.6 \mathrm{a}$ & $59.8 \mathrm{a}$ & $0.67 \mathrm{a}$ & 0.77 \\
Sour orange & Mixed & $12.2 \mathrm{ab}$ & $2.4 \mathrm{ab}$ & $66.5 \mathrm{a}$ & $0.63 \mathrm{ab}$ & 0.70 \\
& None & $5.5 \mathrm{~b}$ & $1.5 \mathrm{~b}$ & $12.6 \mathrm{~b}$ & $0.14 \mathrm{c}$ & 0.82 \\
& G. mosseae & $7.8 \mathrm{a}$ & $2.0 \mathrm{a}$ & $28.5 \mathrm{~b}$ & $0.29 \mathrm{bc}$ & 0.69 \\
& G. intraradices & $9.1 \mathrm{a}$ & $2.0 \mathrm{a}$ & $58.6 \mathrm{a}$ & $0.54 \mathrm{a}$ & 0.60 \\
& Mixed & $8.8 \mathrm{a}$ & $1.9 \mathrm{ab}$ & $51.8 \mathrm{a}$ & $0.45 \mathrm{ab}$ & 0.56 \\
\hline
\end{tabular}

$\overline{{ }^{2}}$ The data are means of 10 replications. Mean separation within column and rootstock by Tukey's HSD $(P=$ $0.05)$.

Table 3. Relative mycorrhizal dependency $\left(\mathrm{RMD}^{2}\right)$ of Swingle citrumelo, Troyer citrange, Cleopatra mandarin, and sour orange on Glomus intraradices, G. mosseae, and a mixture of the two species plus G. aggregatum (mixed inoculum).

\begin{tabular}{lccc}
\hline \hline & \multicolumn{3}{c}{ Inoculum } \\
\cline { 2 - 4 } Rootstock & G. mosseae & G. intraradices & Mixed \\
\hline Swingle citrumelo & 9 & 23 & $54^{*}$ \\
Troyer citrange & 38 & $55^{*}$ & $50^{*}$ \\
Cleopatra mandarin & 25 & $71^{*}$ & $67^{*}$ \\
Sour orange & 53 & $74^{*}$ & $70^{*}$ \\
\hline
\end{tabular}

${ }^{{ }^{2} \mathrm{RMD}}=(\mathrm{MP}-$ nonMP $) \cdot(\mathrm{MP})^{-1} \cdot 100(\mathrm{MP}=$ shoot dry weight mycorrhizal plant, nonMP $=$ shoot dry weight nonmycorrhizal plant).

"Significantly different from the control according to Tukey's HSD $(P=0.05)$.

Table 4. Percentage of root colonization of citrus rootstocks inoculated with Glomus intraradices, $G$. mosseae, and a mixture of the two species plus G. aggregatum (mixed inoculum) with different systems:

1) localized inoculum;2) uniform distribution of the inoculum in the substrate; 3 ) one layer of inoculum; 4) inoculum distributed in the container seedbed; and inoculation with 5) mycorrhizal roots of Lavandula vera, 6) Thymus vulgaris, and 7) Rosmarinus officinalis. ${ }^{2}$

\begin{tabular}{|c|c|c|c|c|}
\hline $\begin{array}{l}\text { Inoculation } \\
\text { system }\end{array}$ & $\begin{array}{c}\text { Swingle } \\
\text { citrumelo }\end{array}$ & $\begin{array}{c}\text { Troyer } \\
\text { citrange }\end{array}$ & $\begin{array}{l}\text { Cleopatra } \\
\text { mandarin }\end{array}$ & $\begin{array}{c}\text { Sour } \\
\text { orange }\end{array}$ \\
\hline \multicolumn{5}{|c|}{ G. intraradices } \\
\hline 1 & $0 \mathrm{~d}$ & $55 \mathrm{a}$ & $76 \mathrm{ab}$ & $65 a-c$ \\
\hline 2 & $7 \mathrm{~cd}$ & $63 \mathrm{a}$ & $84 \mathrm{a}$ & $80 \mathrm{a}$ \\
\hline 3 & $13 \mathrm{ab}$ & $35 \mathrm{a}$ & $67 \mathrm{~b}$ & $56 \mathrm{~cd}$ \\
\hline 4 & $14 \mathrm{bc}$ & $40 \mathrm{a}$ & $73 \mathrm{ab}$ & $61 \mathrm{~b}-\mathrm{d}$ \\
\hline 5 & $26 \mathrm{a}$ & --- & $76 \mathrm{ab}$ & $53 \mathrm{~cd}$ \\
\hline 6 & $15 \mathrm{ab}$ & --- & $45 \mathrm{c}$ & $42 \mathrm{~d}$ \\
\hline 7 & $20 \mathrm{ab}$ & --- & $69 \mathrm{~b}$ & $51 \mathrm{~cd}$ \\
\hline \multicolumn{5}{|l|}{ G. mosseae } \\
\hline 1 & $4 \mathrm{a}$ & $37 \mathrm{a}$ & $38 \mathrm{a}$ & $24 \mathrm{a}$ \\
\hline 2 & $0 \mathrm{~b}$ & $53 \mathrm{a}$ & $46 \mathrm{a}$ & $7 \mathrm{~b}$ \\
\hline 3 & $0 \mathrm{~b}$ & $6 \mathrm{~b}$ & $15 \mathrm{~b}$ & $0 \mathrm{~b}$ \\
\hline \multicolumn{5}{|c|}{ Mixed inoculum } \\
\hline 1 & $64 \mathrm{ab}$ & $66 \mathrm{a}$ & $86 \mathrm{a}$ & $69 \mathrm{a}$ \\
\hline 2 & $72 \mathrm{a}$ & $68 \mathrm{a}$ & $75 \mathrm{ab}$ & $76 \mathrm{a}$ \\
\hline 3 & $48 \mathrm{~b}$ & $49 \mathrm{a}$ & $65 \mathrm{~b}$ & $56 \mathrm{a}$ \\
\hline
\end{tabular}

${ }^{2}$ The data are means of 10 replicates. Means separation within column and inoculum type by Tukey's HSD $(P=0.05)$.

plants. Growth of Troyer citrange, sour orange, and Cleopatra mandarin was more stimulated by $G$. intraradices and by mixed inoculum than by G. mosseae. Growth of Swingle citrumelo was enhanced only by the mixed inoculum.

Sour orange and Cleopatra mandarin exhibited high dependency with mixed inoculum and G. intraradices (Table 3). Troyer citrange exhibited intermediate dependency with the same inoculum, whereas Swingle citrumelo exhibited low dependency with $G$. mosseae and $G$. intraradices and intermediate dependency with mixed inoculum. For the four rootstocks used, inoculation with $G$. mosseae did not increase plant growth significantly compared to control plants.

Greenhouse inoculation systems. Glomus intraradices colonized roots of all rootstocks irrespective of the inoculation method, except for localized inoculum for Swingle citrumelo (Table 4).
Root colonization with G. mosseae was less than with $G$. intraradices in all the rootstocks and by all inoculation methods, especially with one-layer inoculation (system 3). Swingle citrumelo was well colonized only by mixed inoculum. Precropping with various aromatic plants infected with $G$. intraradices produced significant colonization in the container seedbeds, similar to that for other inoculation systems.

Inoculum density. Six weeks after inoculation, G. mosseae as spore inoculum had colonized leek plants $\approx 10 \% \pm 3 \%$ (mean of six plants \pm SD), whereas leek plants inoculated with colonized root fragments and sour orange plants inoculated with spores or root fragments were not infected. After 12 weeks, colonization of leek plants by spore inoculum reached $58 \% \pm 25 \%$ and colonization by root fragment inoculum was only $6 \% \pm 4 \%$. Sour orange roots were not colonized by either spore or root fragment inoculum.

The MPN (AM propagules/100 $\mathrm{cm}^{3}$ of inoculum) obtained with $G$. mosseae inoculum in leek was 1170, 456 for Cleopatra mandarin, 273 for Troyer citrange, and 74 for sour orange and Swingle citrumelo. The same inoculum was more infective for leek, Cleopatra mandarin, and Troyer citrange (in this order) than for Swingle citrumelo and sour orange.

\section{Discussion}

Glomus species were the most common AM fungi found in citrus soils. Glomusmosseae was found directly in the soil and, after the trapping process, at all the sites. Glomus intraradices was recovered using roots of citrus as a source of inoculum, but was not found directly in the soil samples because $G$. intraradices forms spores principally in the roots. Glomus aggregatum and $G$. microaggregatum were recovered during the trapping process. The other species of Glomus were less abundant and were not present in all sites.

Spores belonging to other genera were observed in soil from citrus orchards and nurseries but were not recovered during isolation. Spores of Acaulospora, Gigaspora, Sclerocystis, and Scutellospora were scarce in the soil samples, but their presence cannot be associated with citrus roots.

Host rootstocks had no effect on the AM fungal population composition. The number of mycorrhizal propagules in the soil was affected by host age. The MPN was higher in seedbeds and nurseries than in old orchards.

The most effective fungus for promoting growth was $G$. intraradices, and the most infective inoculum was the mixed one. Glomus mosseae was less effective and infective at the same time. The relationship between effectiveness of AM fungus (ability to stimulate growth) and its infectivity (ability to colonize roots) appears to vary depending on fungus and host. Graham and Fardelman (1986) did not find a clear relationship between root colonization and nutrient uptake and growth response of Carrizo citrange. Differences in the ontogeny of the plant species and in inocu- 
lum type and species of AM fungi could explain these results (Abbot and Robson, 1985). The colonization with $G$. intraradices would be more effective due to its capacity to colonize rapidly and form an extensive and effective network of external hyphae around the root for nutrient acquisition (Abbott and Robson, 1985; Graham et al., 1982).

There were substantial differences in mycorrhizal dependency among rootstocks. Sour orange and Cleopatra mandarin were more dependent than Troyer citrange and Swingle citrumelo. Swingle citrumelo was only well colonized by mixed inoculum containing $G$. mosseae, G. intraradices, and G. aggregatum. Single species of Glomus colonized roots of Swingle citrumelo poorly. The mixed inoculum consisting of a bulk mixture of species appeared to be more infective than a single species of AM fungus.

Other studies have correlated differences in AM dependency of citrus rootstocks to the AM fungus used. The results reported by Graham and Syvertsen (1985) were similar to ours, using $G$. intraradices as a symbiont. The general conclusion is that sour orange and Cleopatra mandarin are more dependent than trifoliate orange and its hybrids (Troyer citrange and Swingle citrumelo).

Colonization with $G$. intraradices in the citrus seedbed also was produced by inoculation with mycorrhizal aromatic plants; $L$. vera and $R$. officinalis were more effective host species than $T$. vulgaris as inoculum sources to infect citrus roots, probably because $T$. vulgaris roots grow slowly in the first stages of development (Camprubí et al., 1992).

Inoculation with $G$. intraradices and mixed inoculum was successful with either localized or distributed inoculum in the substrate. Glomus mosseae was not as effective or infective in citrumelo and sour orange regardless of the inoculation method used.

The lower infectivity of $G$. mosseae may be explained by a greater inoculum density required to produce an effective mycorrhizal infection in Swingle citrumelo and sour orange than in Troyer citrange and Cleopatra mandarin. Moreover, roots colonized with $G$. mosseae are less infective as sources of inoculum than resting spores. We can conclude that G. mosseae inoculum with spores, mycelium, roots, and soil representing the complete life cycle of the fungus is more infective than the inoculum consisting only of the intraradical phase of the fungus produced in a shorter time.

The isolation of native fungi adapted to specific edaphic conditions, the selection of the most effective AM fungi, and an adaptable and reliable inoculation method can ensure the success of mycorrhizal inoculation in largescale production.

\section{Literature Cited}

Abbott, L.K. and A.D. Robson. 1985. Formation of external hyphae in soil by four species of vesicular-arbuscular mycorrhizal fungi. New Phytol. 99:245-255.

Camprubí, A., C. Calvet, V. Estaún, and J. Pera. 1987. Aislamiento de un hongo formador de micorrizas vesículo-arbusculares y ensayo de su efectividad en crisantemo y fresa. Investigación Agraria: Producción y Protección Vegetales 2:281-294.

Camprubí, A., V. Estaún, and C. Calvet. 1992. Effect of aromatic plant species on vesiculararbuscular mycorrhizal establishment in Pistacia terebinthus. Plant \& Soil 139:299-301.

Fisher, R.A. and F. Yates. 1963. Statistical tables for biological, agricultural and medical research. Oliver and Boyd, Edinburg.

Gerdemann, J.W. and T.H. Nicolson. 1963. Spores of mycorrhizal Endogone extracted from soil by wet sieving and decanting. Trans. Brit. Mycol. Soc. 46:235-244.

Giovannetti, M. and B. Mosse. 1980. An evaluation of techniques for measuring vesicular-arbuscular mycorrhizal infection in roots. New Phytol. 87:489-500.

Graham, J.H. 1986. Citrus mycorrhizae: Potential benefits and interactions with pathogens. HortScience 21:1302-1306.
Graham, J.H., D.M. Eissenstat, and D.L. Drouillard. 1991. On the relationship between a plant's mycorrhizal dependency and rate of vesiculararbuscular mycorrhizal colonization. Functional Ecol. 5:773-779.

Graham, J.H. and D. Fardelmann. 1986. Inoculation of citrus with root fragments containing chlamidospores of the mycorrhizal fungus Glomus intraradix. Can. J. Bot. 64:17391744.

Graham, J.H., R.G. Linderman, and J.A. Menge. 1982. Development of external hyphae by different isolates of mycorrhizal Glomus sp. in relation to root colonization and growth of Troyer citrange. New Phytol. 91:683.

Graham, J.H. and J.P. Syvertsen. 1985. Host determinants of mycorrhizal dependency of citrus rootstock seedlings. New Phytol. 101:667-676.

Koske, R.E. and J.N. Gemma. 1989. A modified procedure for staining roots to detect VA mycorrhizas. Mycol. Res. 92:486-505.

Nemec, S. 1978. Response of six citrus rootstocks to three species of Glomus. Proc. Fla. State Hort. Soc. 91:10.

Ortiz, J.M. 1986. Nomenclatura botánica de los cítricos. Fruits 41:199-209.

Phillips, J.M. and D.S. Hayman. 1970. Improved procedure for clearing and staining parasitic and vesicular-arbuscular mycorrhizal fungi for rapid assessment of infection. Trans. Brit. Mycol. Soc. 55:158-161.

Plenchette, C., V. Furlan, and J.A. Fortin. 1983. Responses of endomycorrhizal plants grown in a calcined montmorillonite clay to different levels of soluble phosphorus. I. Effect of growth and mycorrhizal development. Can. J. Bot. 61:1377.

Porter, W.N. 1979. The "most probable number" method for enumerating infective propagules of vesicular-arbuscular mycorrhizal fungi in soil. Austral. J. Soil Res. 17:515-519.

Powell, C.L. 1980. Mycorrhizal infectivity of eroded soils. Soil Biol. Biochem. 12:247-250.

Reed, H. and T. Fremont. 1935. Factors that influence the formation and development of mycorrhizal associations in citrus roots. Phytopathology 25:645.

Schenck, N.C. and Y. Perez. 1988. Manual for the identification of VA mycorrhizal fungi. Univ. of Florida, Gainesville. 